\title{
Controllable synthesis of NaP zeolite and its application in calcium adsorption
}

\author{
Ibraheem O. Ali ${ }^{1}$, Said M. El-Sheikh ${ }^{2}$, Tarek M. Salama ${ }^{1 *}$, Mostafa F. Bakr ${ }^{1}$ and Mohamed H. Fodial ${ }^{1}$
}

\begin{abstract}
$\mathrm{NaP}$ zeolite particles were prepared through a template-free hydrothermal condition at $100^{\circ} \mathrm{C}$. Parameters like $\mathrm{Na}_{2} \mathrm{O} / \mathrm{SiO}_{2}$ and $\mathrm{SiO}_{2} / \mathrm{Al}_{2} \mathrm{O}_{3}$ molar ratios, gel aging time and aging temperature were investigated for regulating the crystallization of the final product. The samples at different synthesis stages were characterized with $\mathrm{N}_{2}$ adsorption at $-196^{\circ} \mathrm{C}$, field emission scanning electron microscopy (FE-SEM), temperature programmed desorption of ammonia adsorption, $\mathrm{X}$-ray diffraction, thermogravimetric and differential scanning calorimetry analysis and Fourier transform infrared spectroscopy. The experimental results evidenced that a high ordering crystallinity of $\mathrm{NaP}$ zeolite was obtained at $\mathrm{Na}_{2} \mathrm{O} / \mathrm{SiO}_{2}$ and $\mathrm{SiO}_{2} / \mathrm{Al}_{2} \mathrm{O}_{3}$ molar ratios of 1.10 and 1.40 , respectively, and a temperature of $100^{\circ} \mathrm{C}$ for 4 days of aging. FE-SEM image exhibited polycrystalline aggregates of $\mathrm{NaP}$ zeolite with crystallite sizes ranging up to $5.04 \mu \mathrm{m}$ with cactus/cabbage like structures. The quantitative analysis of the total number of acid sites was found to increase as $\mathrm{Na}_{2} \mathrm{O}$ increases. The $\mathrm{NaP}$ zeolite sample with a $\mathrm{Na}_{2} \mathrm{O} / \mathrm{SiO}_{2}$ molar ratio of 1.13 exhibited a large fraction of the acid sites on its external surface, contrary to that synthesized with a relevant ratio of 1.10. The optimized NaP zeolite could be successfully bestowed with excellent sorption properties of $\mathrm{Ca}(\mathrm{II})$ in aqueous solution. The kinetic parameters for $\mathrm{Ca}(\mathrm{II})$ adsorption were thoroughly investigated.
\end{abstract}

\section{INTRODUCTION}

Zeolites are crystalline solids with an extending three dimensional network of aluminum and silicon tetrahedra linked by sharing of oxygen atoms $[1,2]$. The zeolite dimensional framework contains repeating cavities and channels, wherein monovalent and divalent cations, water and/or small molecules may reside inside. They are found to have particular applications in heterogeneous catalysis, petroleum refining, ion exchange, chemical separation, adsorption, host/guest chemistry, microelectronic devices, optics, and membranes $[3,4]$. Such applications of zeolites are strongly influenced by the particle morphology, pore size and architecture, and type of channels. In order to improve functional performance of the different kinds of zeolites, many studies have been devoted to improving synthetic approaches to control crystal size, the size of the intracrystalline pore/channel system and morphology of zeolites [5,6].

Among various types of zeolites, $\mathrm{NaP}\left(\mathrm{Na}_{6}\left[\left(\mathrm{AlO}_{2}\right)_{6}\right.\right.$ $\left.\left.\left(\mathrm{SiO}_{2}\right)_{10}\right] \cdot 15 \mathrm{H}_{2} \mathrm{O}\right)$ is one of the most interesting structured zeolite with two sets of intersecting channels: $0.31 \mathrm{~nm} \times$ $0.44 \mathrm{~nm}$ and $0.26 \mathrm{~nm} \times 0.49 \mathrm{~nm}$. According to International Zeolite Association (IZA), this structure is called "Gismondine" (GIS) framework topology [7,8]. NaP zeolite offers the greatest promise for gas separation applications due to its small pore size $[9,10]$, and is also useful for removal of toxic and radioactive waste species like $\mathrm{Cs}, \mathrm{Sr}$, $\mathrm{Ba}, \mathrm{Pb}, \mathrm{U}$, heavy metals, and ammonium from wastewater, seawater potassium extraction and formation of environmental friendly detergent $[11,12]$.

$\mathrm{NaP}$ zeolite can be synthesized from various precursor materials and various methods. It can be synthesized from: (i) clay at a crystallization temperature of $85^{\circ} \mathrm{C}$ [13], (ii) sodium silicate solution [14], and (iii) high silicon fly ash of coal combustion at $120^{\circ} \mathrm{C}$ for $4 \mathrm{~h}$ [15]. Among them the most common methods used for the synthesis of $\mathrm{NaP}$ zeolite are the sol-gel technique, hydrothermal synthesis and microwave heating synthesis [1]. The NaP zeolite with different morphologies can offer many intriguing properties: places to store the guest molecules and to perform chemical reactions with selected-sized molecules. Thus, the $\mathrm{NaP}$ zeolite morphology and its important correlation with properties is the need of the recent research.

In this work, we attempted the template free hydrothermal synthesis of $\mathrm{NaP}$ under controlled conditions. Based on multiple paths that can be involved in the hydrothermal synthesis of $\mathrm{NaP}$, optimization of crystallization conditions was adapted through variation of the following parameters: $\mathrm{Na}_{2} \mathrm{O} / \mathrm{SiO}_{2}$ and $\mathrm{SiO}_{2} / \mathrm{Al}_{2} \mathrm{O}_{3}$ molar ratios, aging time and aging temperature. The characteristics of the synthesized gels

\footnotetext{
${ }^{1}$ Department of Chemistry, Faculty of Science, Al-Azhar University, Nasr City 11884, Egypt

${ }^{2}$ Nanostructured Materials Lab, Advanced Materials Department, Central Metallurgical R\&D Institute (CMRDI), Cairo 11421, Egypt

*Corresponding author (email: tm_salama@yahoo.com)
} 
and products were studied by $\mathrm{N}_{2}$ adsorption, field emission scanning electron microscopy (FE-SEM), temperature programmed desorption of ammonia adsorption ( $\left.\mathrm{NH}_{3}-\mathrm{TPD}\right)$, $\mathrm{X}$-ray diffraction (XRD), thermogravimetric (TG) and differential scanning calorimetry (DSC) analysis and Fourier transform infrared (FTIR) spectroscopy. The efficiency of the synthesized $\mathrm{NaP}$ zeolite was then tested for sorption of $\mathrm{Ca}$ (II) ions from aqueous solution on the optimum condition and the kinetic parameters were determined.

\section{EXPERIMENTAL SECTION}

\section{Materials}

All the chemicals used were of analytical grade and taken without further purification or modification: sodium aluminate $\left(\mathrm{Al}_{2} \mathrm{O}_{3}\right.$ 50-56 wt.\%, $\mathrm{Na}_{2} \mathrm{O} 40-45$ wt.\%, Sigma-Aldrich), silica fume (Sigma-Aldrich, fume 99.8\%, melting point $1700^{\circ} \mathrm{C}$ ) and sodium hydroxide pellets (99\%, Merck). $\mathrm{CaCl}_{2}$ solution $\left(0.025 \mathrm{~mol} \mathrm{~L} \mathrm{~L}^{-1}\right.$, BIOMED Diagnostics) and Arsenazo III (synonyms 2,7-bis(2-arsonohyenylazo)-1,8-dihydroxy-3, 6-naphthalene disulfonic acid or 2,2'-[1,8-dihydroxy-3,6-disulfo-2,7-naphthalene-bis(azo) dibenzenearsonic acid)], $\mathrm{C}_{22} \mathrm{H}_{18} \mathrm{As}_{2} \mathrm{~N}_{4} \mathrm{O}_{14} \mathrm{~S}_{2}$, molecular weight 776.37, 80\%, Egyptian Company for Biotechnology) were used for the spectrophotometric determination of $\mathrm{Ca}(\mathrm{II})$.

\section{Synthesis of NaP zeolite}

The hydrogel was prepared by dissolving a specific amount of $\mathrm{NaOH}$ in $20 \mathrm{~mL}$ of distillate water and silica fume $(2.5 \mathrm{~g}$ ) in $40 \mathrm{~mL}$ of distillate $\mathrm{H}_{2} \mathrm{O}$ with stirring. Then both of them were mixed together and stirred at room temperature and followed by heating at $80^{\circ} \mathrm{C}$ until a clear solution was obtained (solution A). A similar process was repeated by dissolving sodium aluminate $(3.2 \mathrm{~g})$ in $45 \mathrm{~mL}$ of distillate water, and a specific amount of $\mathrm{NaOH}$ in $20 \mathrm{~mL}$ of distillate water under stirring. Then both solutions were mixed together and stirred at ambient temperature until a clear solution was obtained (solution B). Solution B was added slowly to solution A with vigorous stirring. After the complete addition, the gel was formed and aged at room temperature for $30 \mathrm{~min}$ with vigorous stirring to get a homogeneous gel-mix, and then it was transferred to a stainless-steel autoclave ( $300 \mathrm{~mL}$ capacity). The sealed autoclave was placed in an air oven at $100^{\circ} \mathrm{C}$ for 4 days. The produced materials were then filtered, washed with water and dried at $100^{\circ} \mathrm{C}$ for $8 \mathrm{~h}$.

\section{Effect of $\mathrm{Na}_{2} \mathrm{O} / \mathrm{SiO}_{2}$ molar ratio}

The relative amounts $(x)$ of $\mathrm{Na}_{2} \mathrm{O}$ were varied with keeping the other component amounts constant as follows:

$$
x \mathrm{Na}_{2} \mathrm{O}: 1.76 \mathrm{Al}_{2} \mathrm{O}_{3}: y \mathrm{SiO}_{2}: 125 \mathrm{H}_{2} \mathrm{O},
$$

where $1.04 \leqslant x / y \leqslant 1.13$.

\section{Effect of $\mathrm{SiO}_{2} / \mathrm{Al}_{2} \mathrm{O}_{3}$ molar ratio}

The $x \mathrm{SiO}_{2} / y \mathrm{Al}_{2} \mathrm{O}_{3}$ ratios were varied between $1.10 \leqslant x / y \leqslant$ 5.70 according to a gel composition:

$$
\text { 2.76 } \mathrm{Na}_{2} \mathrm{O}: y \mathrm{Al}_{2} \mathrm{O}_{3}: x \mathrm{SiO}_{2}: 125 \mathrm{H}_{2} \mathrm{O} \text {. }
$$

The $\mathrm{Na}_{2} \mathrm{O} / \mathrm{SiO}_{2}$ and $\mathrm{H}_{2} \mathrm{O} / \mathrm{SiO}_{2}$ ratios in the gel route were kept constant at 1.10 and 16.0 , respectively. The resulting gel was homogenized and transferred into the autoclave and allowed to react at $100^{\circ} \mathrm{C}$ for 4 days.

\section{Effects of temperature and crystallization time}

A batch of $\mathrm{NaP}$ zeolite was adopted at an initial molar composition of:

$$
2.76 \mathrm{Na}_{2} \mathrm{O}: 1.76 \mathrm{Al}_{2} \mathrm{O}_{3}: 2.5 \mathrm{SiO}_{2}: 125 \mathrm{H}_{2} \mathrm{O} \text {. }
$$

The temperature to induce crystallization of the $\mathrm{NaP}$ zeolite has been varied from 80 to $140^{\circ} \mathrm{C}$ to have comparable dimensions of different sizes and shapes, while the reaction period was fixed at 4 days. Experiments were also carried out in varied crystallization periods over 2-6 days during the synthesis of the same patch, while the temperature was fixed at $100^{\circ} \mathrm{C}$.

\section{Kinetic experiments}

A measured amount $(0.1 \mathrm{~g})$ of the synthesized $\mathrm{NaP}$ zeolite was added to a measured amount $(50 \mathrm{~mL})$ of aqueous solution of $\mathrm{Ca}$ (II) of different initial concentrations (100-150 $\left.\mathrm{mg} \mathrm{L}{ }^{-1}\right)$, and taken into $250 \mathrm{~mL}$ beakers at $27 \pm 2^{\circ} \mathrm{C}$ and mixed on a magnetic stirrer at $\mathrm{pH} 7.1 .0 \mathrm{~mL}$ sample solution was withdrawn each time from the reaction mixture at a gap of fixed time interval, and filtered using Whatman filter paper to separate the adsorbent particles from the solution. The residual $\mathrm{Ca}(\mathrm{II})$ in sample solution was analyzed by UV-vis spectroscopy at $620 \mathrm{~nm}$ absorbance. The color intensity of a purple complex formed in situ from the reaction of $\mathrm{Ca}$ (II) and Arsenazo III is directly proportional to the adsorption capacity of the samples in the batch-reactor $[16,17]$. The amount of calcium adsorbed was calculated using the relation:

$$
q_{t}=\frac{w_{\mathrm{i}}-w_{\mathrm{r}}}{m}
$$

where $q_{t}$ is the adsorbed amount of calcium per unit mass of the adsorbent $\left(\mathrm{mg} \mathrm{g}^{-1}\right)$ at any time $(t), w_{\mathrm{i}}$ and $w_{\mathrm{r}}$ the initial and residual amount (mg) of calcium added and 
remained in solution, respectively, and $m$ the mass of the adsorbent added $(\mathrm{g})$.

\section{Experimental techniques}

Phase identification, purity, relative crystallinity and crystallite size of the products were analyzed with X-ray diffractometer (Panalytical X'Pert Pro, Netherland) using $\mathrm{Cu}-\mathrm{Ka}$ as a source radiation and nickel filter at a scanning speed of $2^{\circ} \mathrm{min}^{-1}$ in the $2 \theta$ range from $4^{\circ}$ to $70^{\circ}$. The crystallite size was calculated from XRD data by Scherrer equation.

Infrared spectra were recorded by FTIR spectrometer (JASCO 3600 Tokyo, Japan) using KBr tablets.

Brunauer-Emmett-Teller (BET) surface area analyzer (Nova 2000 series, Quanta chrome Instruments, UK) was used to determine the specific surface area $\left(S_{\mathrm{BET}}\right)$, pore volume and pore size distribution of the zeolite samples.

Thermal analysis (DSC-TG) of the NaP zeolite was performed at a heating rate of $10^{\circ} \mathrm{C} \mathrm{min}^{-1}$ from 25 to $1000^{\circ} \mathrm{C}$ in an air flow using a Netzsch-Sta 409 C/CD instrument (Selb, Germany).

The number of acid sites and acid strength of the NaP zeolite were determined by means of temperature programmed desorption of $\mathrm{NH}_{3}$ adsorption ( $\mathrm{NH}_{3}$-TPD) model BELCAT-B, with serial No. CAT-146. The samples were heated from room temperature up to $900^{\circ} \mathrm{C}$ at a heating

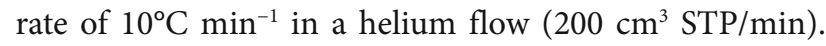
The amount of $\mathrm{NH}_{3}$ desorbed from the sample was monitored by a thermal conductivity detector (W-Re filament).

Size, particle morphology, and aggregation of the $\mathrm{NaP}$ zeolite were monitored by a FE-SEM (Quantafeg 250, Netherlands).

\section{RESULTS AND DISCUSSION}

\section{Verified synthesis of zeolite NaP by XRD}

\section{Effect of $\mathrm{Na}_{2} \mathrm{O} / \mathrm{SiO}_{2}$ molar ratio}

Fig. 1a illustrates the XRD patterns of the synthesized $\mathrm{NaP}$ zeolite samples with different $\mathrm{Na}_{2} \mathrm{O} / \mathrm{SiO}_{2}$ molar ratios, ranging from 1.04 to 1.13 . The patterns of samples made with $\mathrm{Na}_{2} \mathrm{O} / \mathrm{SiO}_{2}$ molar ratio varying from 1.04 to $1.07 \mathrm{ex}-$ hibit crystalline peaks characteristic of both X- and P-type zeolites. When this ratio increased to $1.10, \mathrm{NaP}$ zeolite was detected as the dominant phase (JCPDS No. 71-0962). Thus, a requisite quantity of sodium silicate is needed to tune the composition of the starting gel for crystallization of NaP zeolite. The significant increase in crystallinity of the produced $\mathrm{NaP}$ when the $\mathrm{Na}_{2} \mathrm{O} / \mathrm{SiO}_{2}$ molar ratio is 1.10 could be discussed in terms of the role of $\mathrm{OH}^{-}$groups in increasing the nucleation rate of $\mathrm{NaP}$ zeolite, which properly accounts for the dissolution of the amorphous gel and the formation and release of $\mathrm{NaP}$ zeolite heteronuclei at the gel-solution interface. This may lead to an effective acceleration of the crystal growth and shorten the induction period for the crystal growth of $\mathrm{NaP}$ zeolite [17-20]. Moreover, it was found that increasing the $\mathrm{Na}_{2} \mathrm{O} / \mathrm{SiO}_{2}$ ratio to 1.13 in the synthesis gel resulted in the preservation of the $\mathrm{NaP}$ zeolite matrix, whose degree of crystallinity decreased slightly. This is due to the more density of negative charges involved in the framework structure.

\section{Effect of $\mathrm{SiO}_{2} / \mathrm{Al}_{2} \mathrm{O}_{3}$ molar ratio}

It is well known that the catalytic activity increases with decreasing $\mathrm{SiO}_{2} / \mathrm{Al}_{2} \mathrm{O}_{3}$ molar ratio in a zeolite. This is because as the aluminum content increases, the number of cations existing in the zeolite also increases to balance the negative charges of the zeolite framework. Hence, a series of $\mathrm{NaP}$ zeolite with different $\mathrm{SiO}_{2} / \mathrm{Al}_{2} \mathrm{O}_{3}$ ratios from 1.10 to 5.70 was synthesized and the obtained diffractograms are depicted in Fig. 1b. For a first interacting gel with a $\mathrm{SiO}_{2} /$ $\mathrm{Al}_{2} \mathrm{O}_{3}$ molar ratio of 1.10 , no appearance of $\mathrm{NaP}$ zeolite was observed, but instead, a mixture of zeolite $\mathrm{Y}$ and analcime was formed with a relatively low degree of crystallinity. With increasing $\mathrm{SiO}_{2} / \mathrm{Al}_{2} \mathrm{O}_{3}$ ratio to 1.40 , the product tended to favor the transformation to only $\mathrm{NaP}$ zeolite. A further increase in this ratio up to 2.30 brought about a significant decrease in the structural ordering of $\mathrm{NaP}$ zeolite without revealing any other competitive phases. At a much higher $\mathrm{SiO}_{2} / \mathrm{Al}_{2} \mathrm{O}_{3}$ ratio of 5.70, the $\mathrm{NaP}$ zeolite phase completed disappeared, and the morphology of the gel became amorphous. Basically, these results agree well with those reported by Szostak [21] whereby the nucleation and crystallization rate of $\mathrm{NaP}$ zeolite can be enhanced as follows: (i) as the aluminum content decreases, (ii) with a $\mathrm{SiO}_{2} /$ $\mathrm{Al}_{2} \mathrm{O}_{3}$ ratio above 1.40 and (iii) the lesser the $\mathrm{NaOH}$ concentration, the higher the yield of the crystalline material obtained. Despite keeping the $\mathrm{pH}$ of each gel around 11.0, the total $\mathrm{NaOH}$ concentration of the gel varied depending on the content of $\mathrm{NaAlO}_{2}$ added in order to set the $\mathrm{SiO}_{2}$ / $\mathrm{Al}_{2} \mathrm{O}_{3}$ ratio. Hence, a small amount of $\mathrm{NaOH}$ contained in a gel with a high molar ratio of $\mathrm{SiO}_{2} / \mathrm{Al}_{2} \mathrm{O}_{3}$ would promote the formation of a high $\mathrm{SiO}_{2} / \mathrm{Al}_{2} \mathrm{O}_{3}$ zeolite. This is due to the low relative solubility of the $\mathrm{Al}$ (III) ions with respect to the $\mathrm{Si}(\mathrm{IV})$ ions in alkaline $\mathrm{NaOH}$ solution.

\section{Effect of hydrothermal treatment}

The effect of hydrothermal aging in the range of $80-120^{\circ} \mathrm{C}$ on better control of $\mathrm{NaP}$ zeolite crystal growth was thoroughly investigated by XRD (Fig. 1c). The gel composition of the starting mixture was kept constant at $\mathrm{SiO}_{2} / \mathrm{Al}_{2} \mathrm{O}_{3}$ and $\mathrm{Na}_{2} \mathrm{O} / \mathrm{SiO}_{2}$ molar ratios of 1.40 and 1.10 , respectively. 


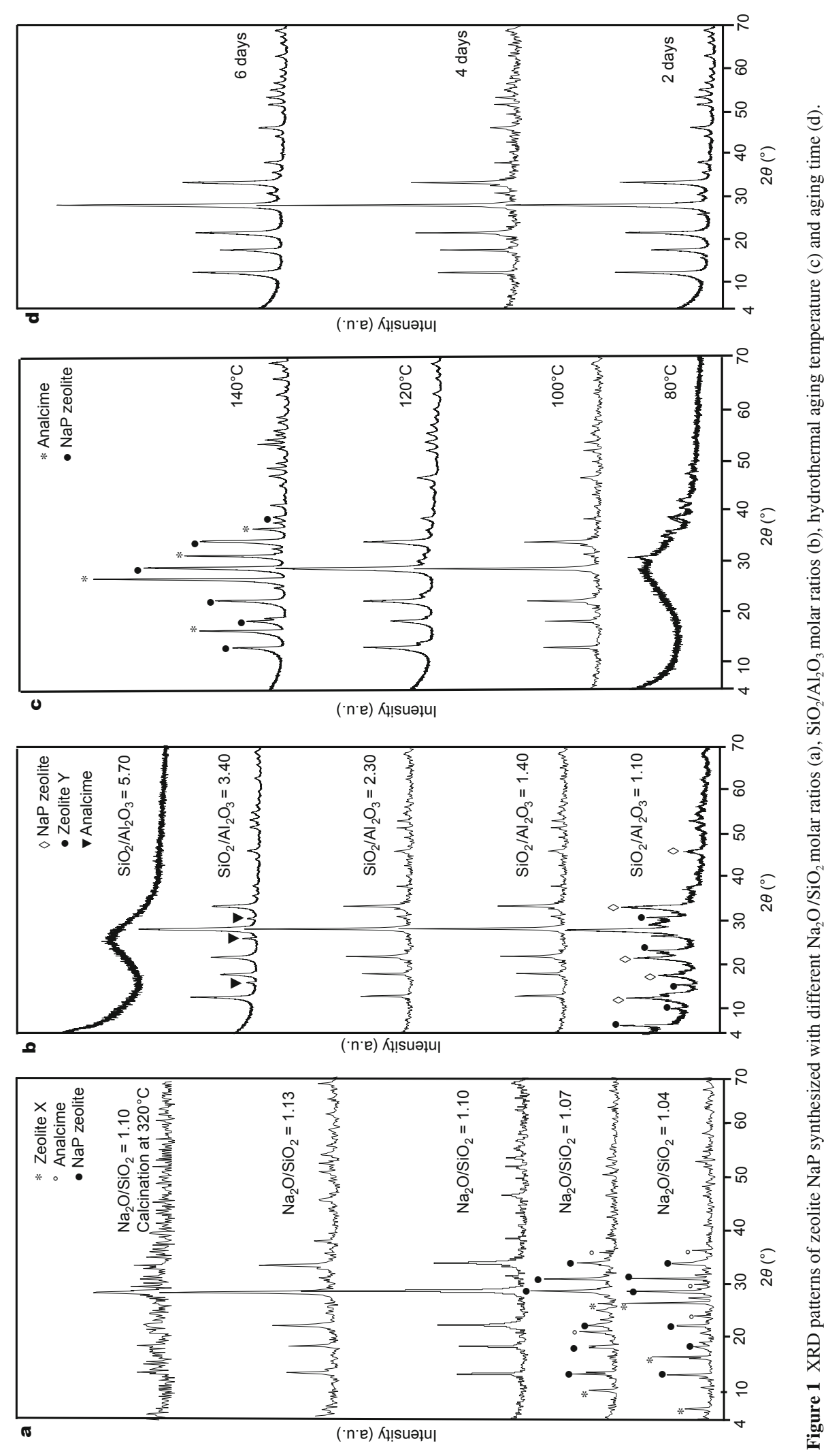


Initially, crystallization of $\mathrm{NaP}$ zeolite was insufficient at a temperature below $80^{\circ} \mathrm{C}$, whereas the reflections reached maximum intensity at $100^{\circ} \mathrm{C}$. Thus, a temperature of $100^{\circ} \mathrm{C}$ was considered to be optimum for getting the highest degree of $\mathrm{NaP}$ zeolite crystallinity. As the aging temperature increases to $120^{\circ} \mathrm{C}$, the $\mathrm{NaP}$ pattern exhibits an overall reduction in the intensities of the reflections due to decreased crystal size. A further increase in temperature to $140^{\circ} \mathrm{C}$ results in crystal growth of the analcime parallel to NaP zeolite. In agreement with previous reports [22], the sequence of formation of the products with the increase in temperatures was in the direction: transient amorphous phase to $\mathrm{NaP}$ zeolite to analcime.

These results can be interpreted as due to the effect of supercritical concentration of components aluminate and silicate in the liquid phase of the mixture, generally a gel, which is the major controlling factor of zeolite formation [23]. Concentrations of these components are temperaturedependent, i.e. the concentration of the solution changes as the temperature changes. As the temperature increases over $100^{\circ} \mathrm{C}$, the solubility of the aluminate and silicate species increases, causing a shift in the concentration of the liquid phase. As a consequence, an impurity of analcime in the phase of $\mathrm{NaP}$ zeolite would be produced at $140^{\circ} \mathrm{C}$. Hence, if pure $\mathrm{NaP}$ zeolite has to be crystallized at high temperatures, lowering of the $\mathrm{Na}_{2} \mathrm{O} / \mathrm{SiO}_{2}$ ratio is important in the starting mixture to attain relatively low alkalinity.

\section{Effect of aging time}

The effect of aging time on the hydrothermal crystallization of $\mathrm{NaP}$ zeolite under similar conditions, i.e. the $\mathrm{SiO}_{2} /$ $\mathrm{Al}_{2} \mathrm{O}_{3}$ and $\mathrm{Na}_{2} \mathrm{O} / \mathrm{SiO}_{2}$ ratios in the final gel composition at 1.40 and 1.10 , respectively, and a temperature of $100^{\circ} \mathrm{C}$, is shown in Fig. 1d. A comparable crystallization behavior was achieved after hydrothermal aging the mixture over variable amounts of time. The XRD analysis reveals that the time required to achieve a maximum crystallization is 4 days since shorter or longer aging time than this period leads to the lower crystallinity of the zeolite particles. The gel aging do not influence the type of zeolite NaP formed. The primary effect of the gel aging for 4 days is the shortening of the induction period and the acceleration of the crystallization process. The increase in hydrothermal treatment time to 6 days implies a lower degree of crystallinity due to prolonged pressure induced amorphization.

\section{FTIR spectra}

Effect of $\mathrm{Na}_{2} \mathrm{O} / \mathrm{SiO}_{2}$ molar ratio in the vibrational lattice frequencies and the crystallization field of $\mathrm{NaP}$ zeolite synthesized with $\mathrm{Na}_{2} \mathrm{O} / \mathrm{SiO}_{2}=1.13$ and 1.10 molar ratios was

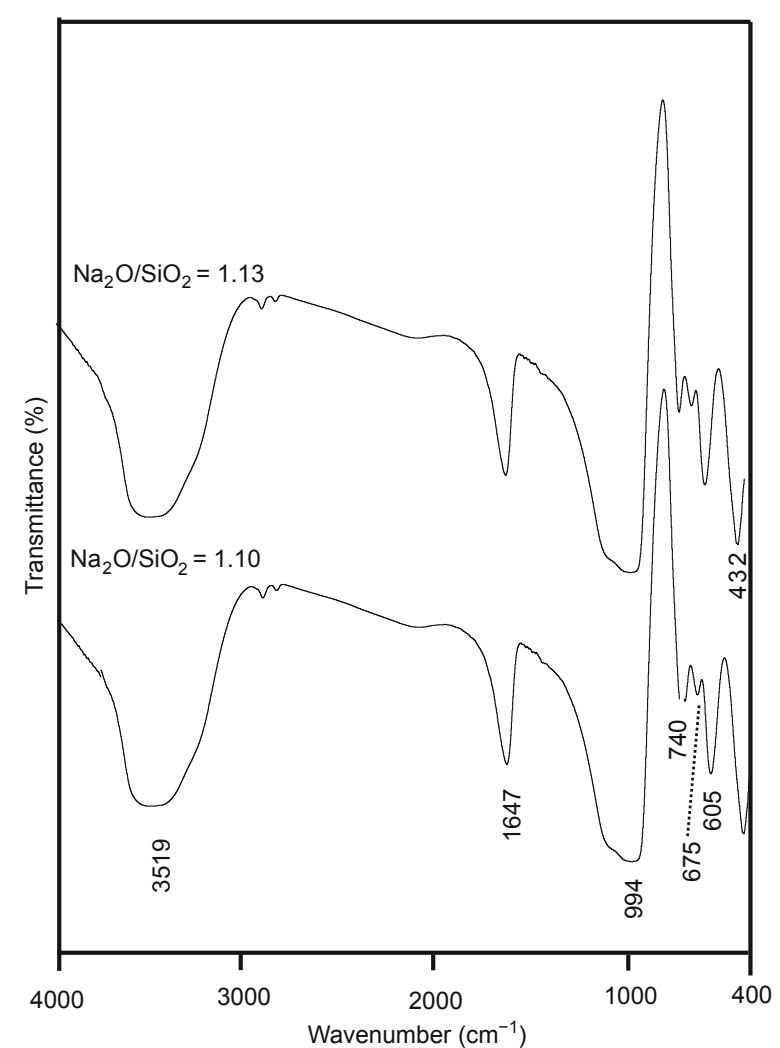

Figure 2 FTIR spectra of zeolite $\mathrm{NaP}$ prepared by using different $\mathrm{Na}_{2} \mathrm{O}$ / $\mathrm{SiO}_{2}$ molar ratios.

examined by FTIR (Fig. 2). The overall vibrations in the infrared spectra of both samples are typical of $\mathrm{NaP}$ zeolite [24]; the fundamental features at 994, 740, 675, 605 and $432 \mathrm{~cm}^{-1}$ were assigned generally to different vibrations of adjacent tetrahedra and framework atoms in the zeolite lattice $[16,24,25]$. The bands at about 994 and $432 \mathrm{~cm}^{-1}$ are due to internal vibrations of $(\mathrm{Si}, \mathrm{Al}) \mathrm{O}_{4}$ tetrahedra of $\mathrm{NaP}$ zeolite which are insensitive to framework structure. These bands result from stretching and bending modes of the $\mathrm{T}-\mathrm{O}(\mathrm{T}=\mathrm{Si}$ or $\mathrm{Al})$ units [16], respectively. The shifting of the T-O band generally located around $1090-1040 \mathrm{~cm}^{-1}$ for aluminosilicates containing five-membered rings to lower frequencies $\left(994 \mathrm{~cm}^{-1}\right)$, indicates zeolitization of the reacted slurry to $\mathrm{NaP}$ zeolite. Musyoka [26] observed a shift from 1053 to $1004 \mathrm{~cm}^{-1}$ and increased absorbance at $1004 \mathrm{~cm}^{-1}$ as the fly-ash/ $\mathrm{NaOH}$ slurry was increasingly converted to $\mathrm{NaP}$ zeolite, with increasing hydrothermal treatment time at a temperature of $100^{\circ} \mathrm{C}$.

The bands at 675 and $740 \mathrm{~cm}^{-1}$ are attributed to the symmetric stretch vibration of internal tetrahedra. The band at $605 \mathrm{~cm}^{-1}$ is due to vibrations related to doubling stretching framework structure [1]. The intensity of this band was 
higher for sample made with the molar ratio of $\mathrm{Na}_{2} \mathrm{O} / \mathrm{SiO}_{2}$ at 1.10 than its analogs at 1.13 , which might suggest a higher ordered and well-defined structure for the former sample than the latter, incompatible with the XRD data. The IR band at $3519 \mathrm{~cm}^{-1}$ was assigned to hydrogen bonded $\mathrm{Si}-\mathrm{OH}$ groups, while the band at $1647 \mathrm{~cm}^{-1}$ was ascribed to the bending vibration mode of residual $\mathrm{H}_{2} \mathrm{O}$ molecules in the zeolite voids $[27,28]$.

\section{Thermal analysis}

TG and DSC thermograms of the uncalcined samples of the synthesized $\mathrm{NaP}$ zeolite with $\mathrm{Na}_{2} \mathrm{O} / \mathrm{SiO}_{2}$ molar ratios of 1.10 and 1.13 are depicted in Fig. 3. The shapes of these TG curves are all similar to the thermal behavior of the synthesized NaP zeolite [8]. These curves are characterized by weight losses of total mass 12.45 and $17.88 \%$ of the former and latter samples, respectively. The first peak at $163^{\circ} \mathrm{C}$ in the profiles of both samples can be attributed to desorption of water molecules present on external and internal surfaces, that accompanied by weight losses of 8.0 and 15.0 wt.\% for samples made with the $\mathrm{Na}_{2} \mathrm{O} / \mathrm{SiO}_{2}$ ratio of 1.10 and 1.13 , respectively. The second peak appeared at around $328^{\circ} \mathrm{C}$ with weight losses of $4.45 \%$ and $2.88 \%$ for the former and latter, respectively, corresponding to decomposition and removal of hydroxyl groups in the synthesized zeolites [28]. This means that the removal of hydroxyl groups in

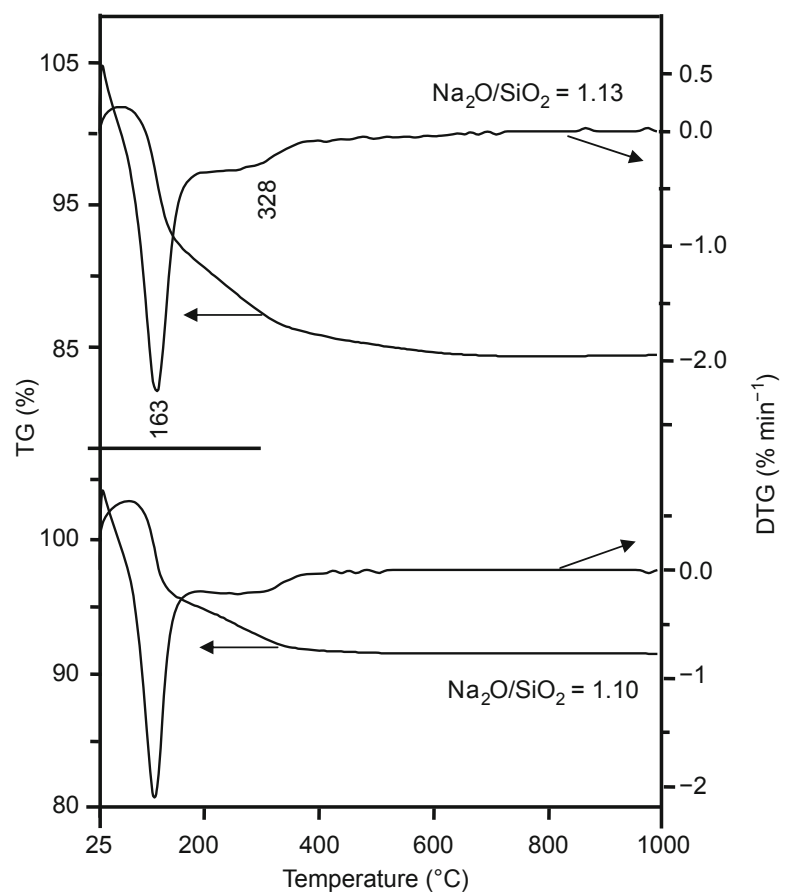

Figure 3 TGA curves of zeolite $\mathrm{NaP}$ prepared by using different $\mathrm{Na}_{2} \mathrm{O}$ / $\mathrm{SiO}_{2}$ molar ratios. the synthesized $\mathrm{NaP}$ zeolite increases with decreasing the $\mathrm{Na}_{2} \mathrm{O} / \mathrm{SiO}_{2}$ molar ratio.

The DSC curves of the two samples showed two thermal effects (Fig. 4). The first endothermic effect with a maximum at $118^{\circ} \mathrm{C}$ was relevant to the release of water molecules from zeolite $\mathrm{NaP}$. The exothermic effect at $328^{\circ} \mathrm{C}$ corresponds to the amorphous to crystalline transformation of $\mathrm{NaP}$ zeolite.

Related to this behavior, the TG curves of the two samples (Fig. 3), present endothermic peak at the same temperature due to condensation of surface silanol groups and/or removal of the chemically bound water [29]. The DSC effect at $328^{\circ} \mathrm{C}$ is more noticeable for the sample with $\mathrm{Na}_{2} \mathrm{O} / \mathrm{SiO}_{2}=1.10$ than the one having $\mathrm{Na}_{2} \mathrm{O} / \mathrm{SiO}_{2}=1.13$. This exothermic peak would be referred to partial decomposition of zeolite $\mathrm{NaP}$ made with the $\mathrm{Na}_{2} \mathrm{O} / \mathrm{SiO}_{2}$ ratio of 1.10 into amorphous $\mathrm{Al}_{2} \mathrm{O}_{3}$ - and $\mathrm{SiO}_{2}$ - like species on $\mathrm{NaP}$ where this sample experienced a disproportionate loss of crystallinity, in agreement with the XRD data of Fig. 1a. It should be noted that the synthetic $\mathrm{P}$ zeolites dominate the synthesis composition fields in the low temperature range (from 100 to $150^{\circ} \mathrm{C}$ ). No further exothermic peaks related to phase transitions of the materials up to $1000^{\circ} \mathrm{C}$ were observed in the DSC curves of both samples to support their thermal stability in this temperature range.

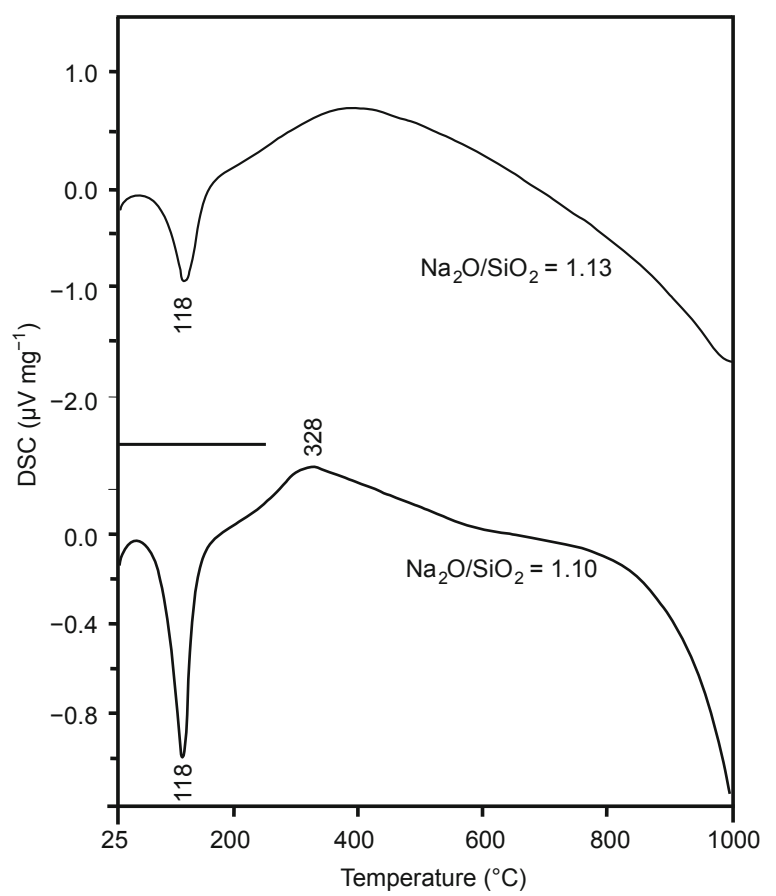

Figure 4 DSC curve of zeolite $\mathrm{NaP}$ prepared by using different $\mathrm{Na}_{2} \mathrm{O}$ / $\mathrm{SiO}_{2}$ molar ratios. 


\section{Morphology and crystal size}

Particle size and morphological evaluation of the synthesized $\mathrm{NaP}$ samples with different $\mathrm{Na}_{2} \mathrm{O} / \mathrm{SiO}_{2}$ (1.10 and 1.13) molar ratios were investigated by FE-SEM (Fig. 5). The difference in the $\mathrm{Na}_{2} \mathrm{O} / \mathrm{SiO}_{2}$ ratio caused a slight difference in the average particle size of the samples. According to the FE-SEM image, the sample with a molar ratio $\mathrm{Na}_{2} \mathrm{O} / \mathrm{SiO}_{2}$ of 1.10 exhibits cactus/cabbage-like morphology, which is characterized by polycrystals with an average size ranging up to $5.19 \mu \mathrm{m}$. The predominance of zeolite $\mathrm{NaP}$ as the final crystalline product is confirmed by the morphology development of such cactus/cabbage forms. These results are similar to those presented by Zubowa et al. [1], in which $\mathrm{NaP}$ zeolite was identified as pseudo-spherical forms constituted by small plates. When the $\mathrm{Na}_{2} \mathrm{O} / \mathrm{SiO}_{2}$ ratio is 1.13 , $\mathrm{NaP}$ zeolite was formed with a relatively smaller size, i.e. $5.04 \mu \mathrm{m}$. Likewise, the morphology of this sample is retained in cactus/cabbage forms. The enhanced nucleation might be responsible for the formation of smaller particle size in the sample with $\mathrm{Na}_{2} \mathrm{O} / \mathrm{SiO}_{2}=1.13$.
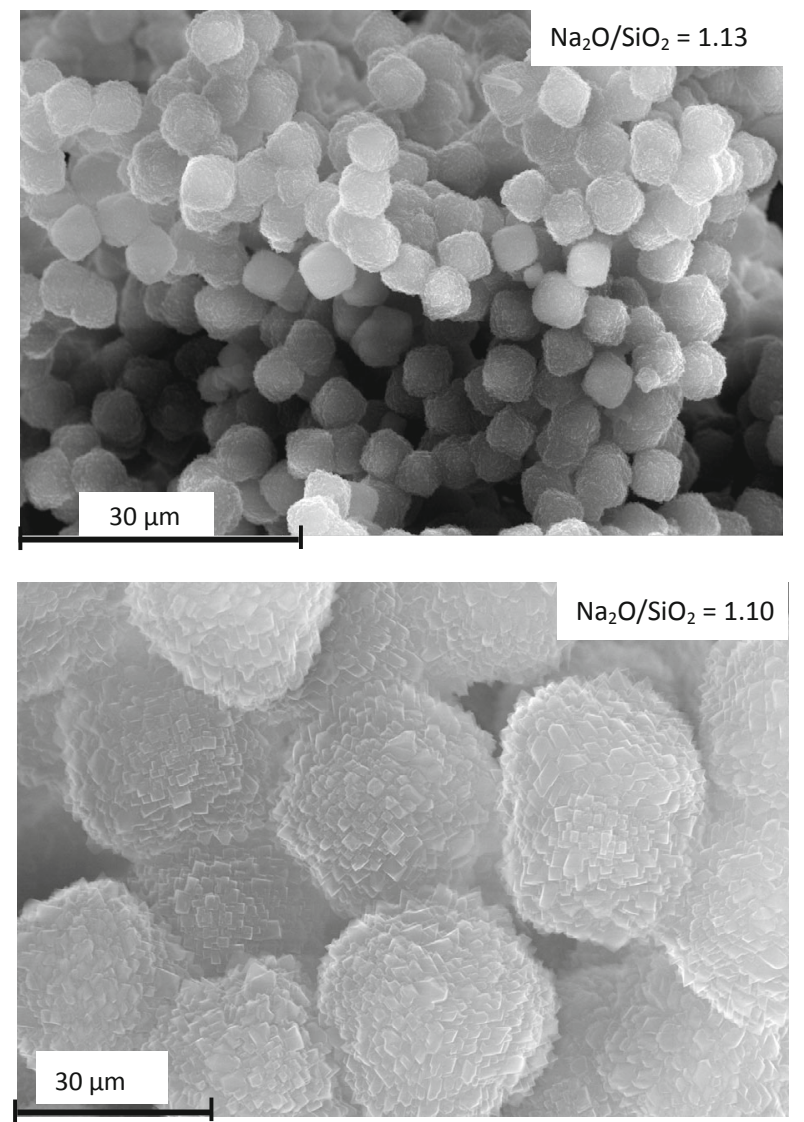

Figure 5 SEM images of zeolite $\mathrm{NaP}$ prepared by using different $\mathrm{Na}_{2} \mathrm{O}$ / $\mathrm{SiO}_{2}$ molar ratios.

\section{Temperature programmed desorption of $\mathrm{NH}_{3}$}

$\mathrm{NH}_{3}$-TPD was used to measure the acid strength and the acid sites distribution on the surfaces of the samples with different $\mathrm{Na}_{2} \mathrm{O} / \mathrm{SiO}_{2}$ molar ratios (Fig. 6). The $\mathrm{NH}_{3}-\mathrm{TPD}$ profiles for both samples revealed two desorption peaks; a low temperature (LT) peak at $381^{\circ} \mathrm{C}$ and a high temperature (HT) peak at $442^{\circ} \mathrm{C}$ (Fig. 6). This leads to the assumption that at least two types of acid sites exist in both samples. The LT-peak represents intermediate strength, of acidic sites and assigned to the desorption of ammonia bound via hydrogen bonds to $\mathrm{NH}_{4}^{+}$, i.e. $\left(\mathrm{NH}_{3}\right)_{n} \mathrm{NH}_{4}{ }^{+} / \mathrm{Zeo}^{-}$adsorbate, and proton transport is assumed to follow a Grotthus-like mechanism [30,31]. It can be seen from the TPD profiles that the $\mathrm{NaP}$ sample with the higher $\mathrm{Na}_{2} \mathrm{O} / \mathrm{SiO}_{2}$ molar ratio exhibited a large fraction of acid sites, contrary to that synthesized with the lower ratio.

The HT-peak may be attributed to the decomposition of the stoichiometric adsorption complexes, i.e. the $\mathrm{NH}_{4}^{+}$/ $\mathrm{Zeo}^{-}$ion-pair complex, which formed by interaction with strong acidic Brønsted sites related to framework aluminum atoms. The majority of the structural Brønsted acid sites are located in the pores, only small amounts of Brønsted acid sites are on the outer surface of the NaP particles. The total number of acid sites initially increased from 1.89 to $4.43 \mathrm{mmol} \mathrm{g}{ }^{-1}$ when $\mathrm{Na}_{2} \mathrm{O} / \mathrm{SiO}_{2}$ molar ratio increased from 1.10 to 1.13 , respectively. This can be explained by the removal of the extra framework debris in the former and thus generating mesopore-modified zeolite $\mathrm{P}$, which

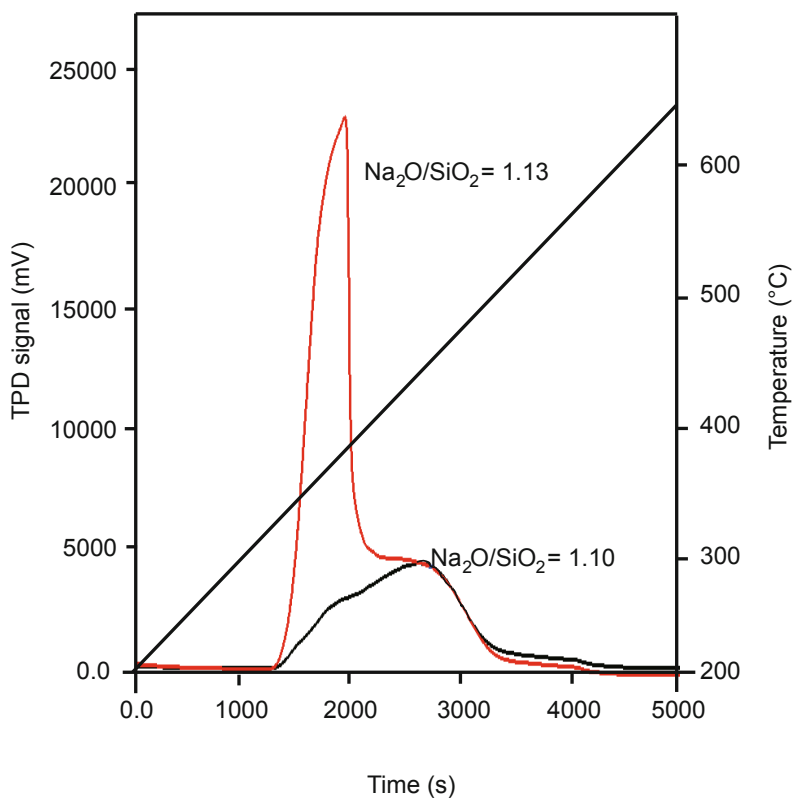

Figure $6 \mathrm{NH}_{3}$-TPD of zeolite $\mathrm{NaP}$ prepared by using different $\mathrm{Na}_{2} \mathrm{O}$ / $\mathrm{SiO}_{2}$ molar ratios. 
would best describe the higher total acidity of this sample. This is confirmed by the prevalence of wide pore volume $\left(V_{\mathrm{p}}^{\text {wid }}\right)$ and surface area of wide pores $\left(S^{\text {wid }}\right)$ of this sample in which diffusion limitation was almost absent. Besides, the larger surface area of $\mathrm{NaP}$ zeolite made with the $\mathrm{Na}_{2} \mathrm{O} / \mathrm{SiO}_{2}$ molar ratio of 1.13 , as shown below, provides more sites for chemisorption of ammonia.

\section{Surface texture}

Surface characteristics of $\mathrm{NaP}$ zeolite samples prepared with $\mathrm{Na}_{2} \mathrm{O} / \mathrm{SiO}_{2}=1.10$ and 1.13 molar ratios were determined by $\mathrm{N}_{2}$ adsorption/desorption experiments at $-196^{\circ} \mathrm{C}$. Both $\mathrm{NaP}$ zeolite samples show a type IV isotherm characteristic of solids with predominantly mesoporous channels [32] (Fig. 7). Although the validity of the BET model for highly microporous materials is questionable, the surface area derived from this model in the adapted pressure range $P / P^{\circ}=$ 0.01-0.1 can still be used for comparative purposes [33] in Table 1. The specific surface areas were 6.16 and $13.63 \mathrm{~m}^{2}$ $\mathrm{g}^{-1}$, while pore volumes were 0.012 and $0.0022 \mathrm{~cm}^{3} \mathrm{~g}^{-1}$ for samples made with $\mathrm{Na}_{2} \mathrm{O} / \mathrm{SiO}_{2}=1.10$ and 1.13, respective- ly. Thus, the latter sample exhibits a higher surface area and a lower pore volume, which is likely due to lower particle size of this sample as confirmed by XRD and FE-SEM. It can be seen that all surface area values were rather small, similar to those reported values in the literature, which could be attributed to the fact that $\mathrm{NaP}$ zeolite only had 8 -membered rings in the structure $[8,34]$.

Micropore-size distribution of both zeolite samples was calculated using HK-pore-size distributions method [35]. The HK method can be applied to differentiate micro pore size distribution maxima located close to each other in a physical mixture of two different zeolite materials as shown in Fig. 7 (inset). The HK profile of zeolite $\mathrm{NaP}$ with $\mathrm{Na}_{2} \mathrm{O}$ / $\mathrm{SiO}_{2}=1.10$ indicates the presence of micropores with a maximum pore size of $3.0 \mathrm{~nm}$. Alternatively, the absence of a point of inflection in the high-resolution isotherm of the $\mathrm{NaP}$ sample with $\mathrm{Na}_{2} \mathrm{O} / \mathrm{SiO}_{2}=1.13$ is a direct evidence for the absence of micropores in this sample.

\section{Adsorption of $\mathrm{Ca}(\mathrm{II})$ in aqueous solution}

The uptake profiles of $150 \mathrm{mg} \mathrm{L}^{-1}$ initial concentration of

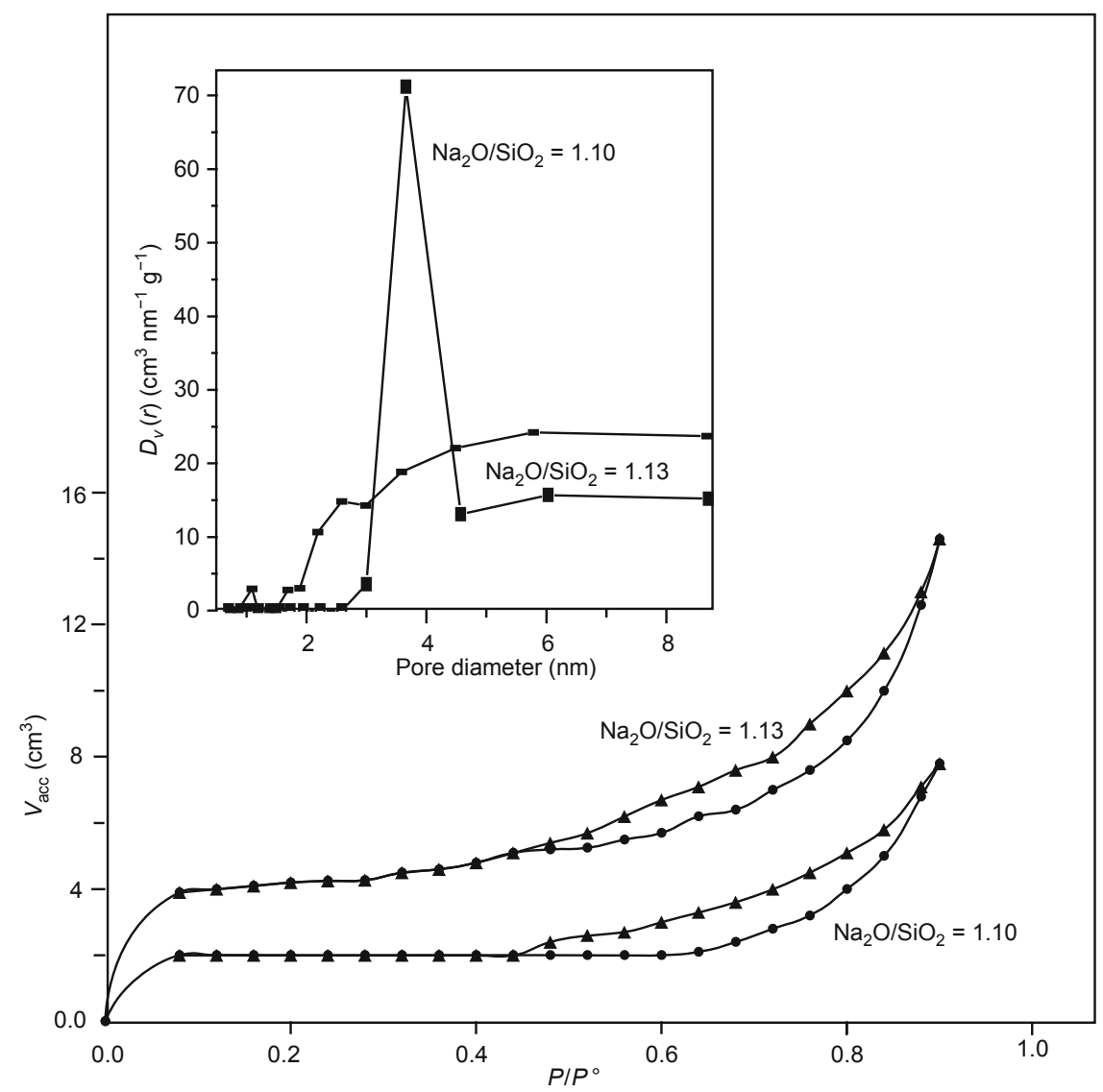

Figure $7 \mathrm{~N}_{2}$ adsorption-desorption isotherms of zeolite $\mathrm{NaP}$ prepared by using different $\mathrm{Na}_{2} \mathrm{O} / \mathrm{SiO}_{2}$ molar ratios. The inset shows the HK-pore-size distributions of the $\mathrm{NaP}$ zeolites. 
Table 1 Surface characteristics of zeolite $\mathrm{P}$ at different ratios of $\mathrm{Na}_{2} \mathrm{O} / \mathrm{SiO}_{2}$ after thermal treatment at $200^{\circ} \mathrm{C}$ under reduced pressure of $10^{-5}$ Torr and nitrogen adsorption at $-196^{\circ} \mathrm{C}$

\begin{tabular}{cccccccccc}
\hline \multicolumn{1}{c}{ Sample } & $S_{\text {BET }}\left(\mathrm{m}^{2} \mathrm{~g}^{-1}\right)$ & $S_{t}\left(\mathrm{~m}^{2} \mathrm{~g}^{-1}\right)$ & $S^{\mu}\left(\mathrm{m}^{2} \mathrm{~g}^{-1}\right)$ & $S^{\text {wid }}\left(\mathrm{m}^{2} \mathrm{~g}^{-1}\right)$ & $S^{\text {ext }}\left(\mathrm{m}^{2} \mathrm{~g}^{-1}\right)$ & $\bar{r}(\AA)$ & $V_{\mathrm{p}}^{\text {total }}\left(\mathrm{cm}^{3} \mathrm{~g}^{-1}\right)$ & $V_{\mathrm{p}}^{\mu}\left(\mathrm{cm}^{3} \mathrm{~g}^{-1}\right)$ & $V_{\mathrm{p}}^{\text {wid }}\left(\mathrm{cm}^{3} \mathrm{~g}^{-1}\right)$ \\
\hline $\mathrm{Na}_{2} \mathrm{O} / \mathrm{SiO}_{2}=1.1$ & 6.2 & 6.5 & 5.3 & 0.9 & 8.6 & 19.0 & 0.0120 & 0.0029 & 0.0091 \\
$\mathrm{Na}_{2} \mathrm{O} / \mathrm{SiO}_{2}=1.13$ & 13.3 & 13.7 & 6.9 & 6.4 & 6.8 & 19.1 & 0.0197 & 0.0037 & 0.016 \\
\hline
\end{tabular}

Note: $\left(S_{\mathrm{BET}}\right)$ BET-surface area; $\left(S_{t}\right)$ surface area derived from $V_{1-t}$ plots; $\left(S^{\text {ext }}\right)$ external surface area; $\left(S^{\mu}\right)$ surface area of micropores; $\left(S^{\text {wid }}\right)$ surface area of wide pores; $\left(V_{\mathrm{p}}^{\text {total }}\right)$ total pore volum $\left(V_{\mathrm{P}}^{\mu}\right)$ pore volume of micropores; $(\bar{r})$ mean pore radius.

$\mathrm{Ca}$ (II) against contact time show that the amount of $\mathrm{Ca}$ (II) adsorbed onto $\mathrm{NaP}$ increases as the $\mathrm{Na}_{2} \mathrm{O} / \mathrm{SiO}_{2}$ ratio increasing from 1.10 to 1.13 at the early stage of adsorption, i.e. up to $5 \mathrm{~min}$ (Fig. 8). The uptake slows near to equilibrium beyond this period of the latter, though the former continued to adsorb $\mathrm{Ca}$ (II) ions up to $15 \mathrm{~min}$. An inflection point in the sorption profiles was observed at $7.2 \mathrm{~min}$. Initially a large number of vacant sorbent sites are available on zeolite $\mathrm{NaP}$ made with the $\mathrm{Na}_{2} \mathrm{O} / \mathrm{SiO}_{2}$ molar ratio of 1.13 , and there is a high concentration gradient between solution and solid interface, thus uptake was fast for the first $5 \mathrm{~min}$, incompatible with the higher surface area of this sample. After this time, occupation of the remaining vacant surface sites is difficult due to repulsive forces between the solute molecules in the $\mathrm{NaP}$ zeolite $\left(\mathrm{Na}_{2} \mathrm{O} / \mathrm{SiO}_{2}=1.13\right)$ and bulk phase, and rate slows down. Between these two stages the rate of uptake is constant.

As can be seen from Fig. 9, the adsorption capacities of $\mathrm{NaP}$ zeolite with the $\mathrm{Na}_{2} \mathrm{O} / \mathrm{SiO}_{2}$ molar ratio of 1.10 , for

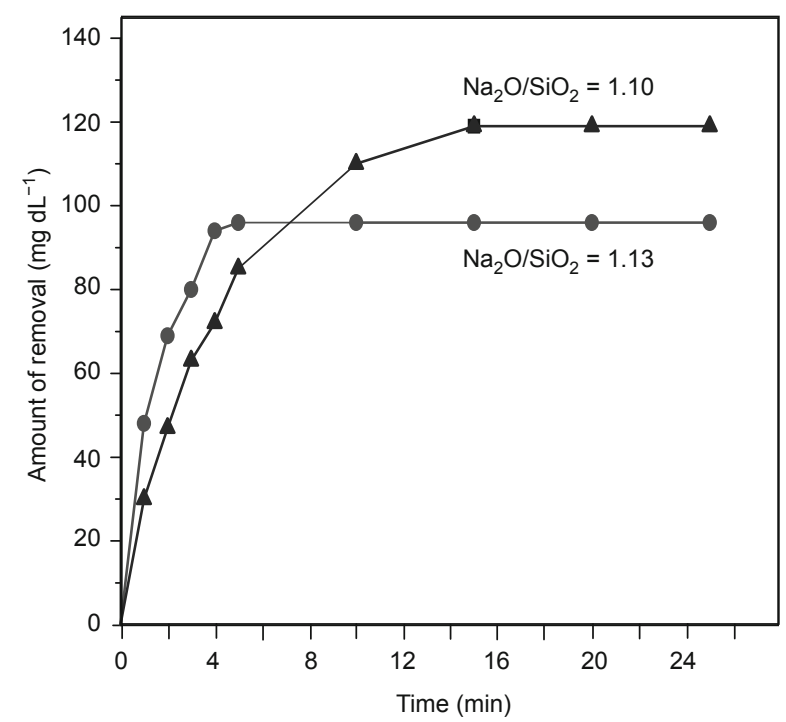

Figure 8 Effect of contact time on the adsorption of $\mathrm{Ca}^{2+}$ from aqueous solution by zeolite $\mathrm{NaP}$ at the following conditions: temperature, $27^{\circ} \mathrm{C}$; initial concentration, $150 \mathrm{mg} / 50 \mathrm{~mL}$; $\mathrm{pH} 7$; adsorbent dosage, 0.1 $\mathrm{g} / 50 \mathrm{~mL}$.

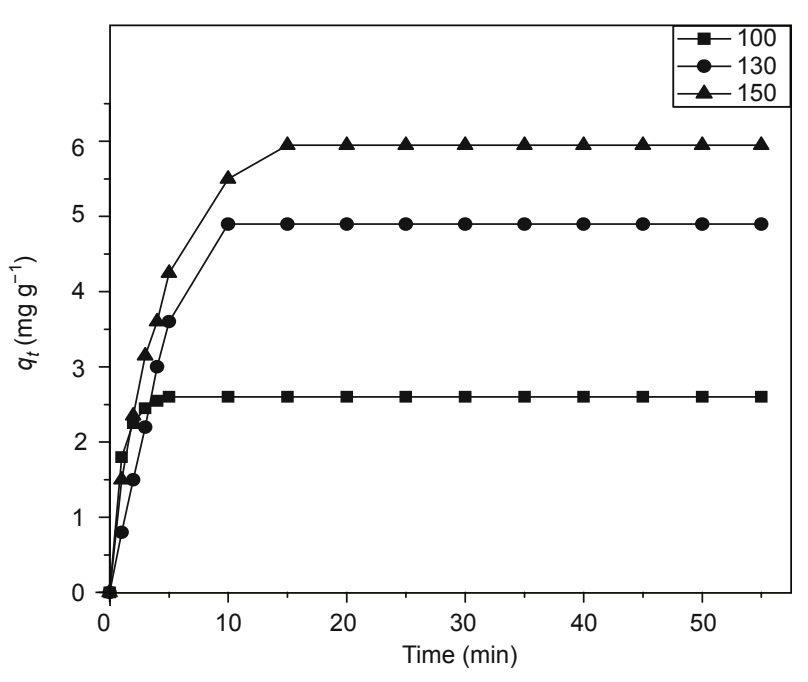

Figure 9 Effect of different concentration of $\mathrm{Ca}^{2+}$ from aqueous solution on adsorption to zeolite $\mathrm{NaP}$.

$\mathrm{Ca}(\mathrm{II})$ ions were observed to increase with the increase of the initial $\mathrm{Ca}$ (II) ion concentrations, i.e. 100, 130 and $150 \mathrm{mg} \mathrm{L}^{-1}$. Also, adsorption of $\mathrm{Ca}$ (II) increased with the contact time. This was attributed to the concentration gradient which can greatly contribute to the driving force for adsorption. High removal rates of $\mathrm{Ca}$ (II), within a few minutes, were observed at the beginning of adsorption process because of the great number of sites available for the sorption uptake. The maximum percentage removal of $\mathrm{Ca}(\mathrm{II})$ has been found to be $79.3 \%$ for $150 \mathrm{mg} \mathrm{L}^{-1}$ initial $\mathrm{Ca}(\mathrm{II})$ concentration, until the equilibrium condition was achieved. The equilibrium began firstly, after $5 \mathrm{~min}$ at a lower concentration of $\mathrm{Ca}(\mathrm{II})$, i.e. $100 \mathrm{mg} \mathrm{L}^{-1}$; then delayed by 10 and $15 \mathrm{~min}$ at 130 and $150 \mathrm{mg} \mathrm{L}^{-1}$, respectively. It is argued that this performance should be similar to the migration volume for "free" vacancies in the framework structure of the $\mathrm{NaP}$ zeolite.

\section{Adsorption isotherm analysis}

The Freundlich and Langmuir isotherms are important for analysis and design of the sorption systems and to fit the 
experimental data. The Langmuir equation was applied to the sorption equilibrium as follows:

$$
\frac{C_{\mathrm{e}}}{q_{\mathrm{e}}}=\frac{C_{\mathrm{e}}}{q_{\max }}+\frac{1}{q_{\max } K_{\mathrm{L}}},
$$

where $q_{\mathrm{e}}$ is the amount of $\mathrm{Ca}(\mathrm{II})$ adsorbed at equilibrium $\left(\mathrm{mmol} \mathrm{g}^{-1}\right), C_{\mathrm{e}}$ is the equilibrium concentration of the solution $\left(\mathrm{mg} \mathrm{L}^{-1}\right), q_{\max }$ is the maximum adsorption capacity $\left(\mathrm{mmol} \mathrm{g}{ }^{-1}\right.$ ) and $K_{\mathrm{L}}$ is a Langmuir constant related to the binding energy of the sorption system $\left(\mathrm{L} \mathrm{g}^{-1}\right)$.

A straight line is obtained by plotting $C_{\mathrm{e}} / q_{\mathrm{e}} v s$. $C_{\mathrm{e}}$, where $K_{\mathrm{L}}$ and $q_{\max }$ could be estimated from the intercept and slope, respectively (Table 2 ). It can be concluded, from the values of $R^{2}$ and the maximum monolayer coverage capacity $\left(q_{\mathrm{m}}\right)$ obtained from Langmuir isotherms on both samples, that there is strong positive evidence that the sorption of $\mathrm{Ca}$ (II) onto $\mathrm{NaP}$ zeolite $\left(\mathrm{Na}_{2} \mathrm{O} / \mathrm{SiO}_{2}=1.10\right)$ has a better agreement with the Langmuir sorption model than the other sample $\left(\mathrm{Na}_{2} \mathrm{O} / \mathrm{SiO}_{2}=1.13\right)$.

The Langmuir isotherm can also be expressed in terms of a dimensionless constant separation factor $\left(R_{\mathrm{L}}\right)$ which is given by the following equation [36]:

$$
R_{\mathrm{L}}=\frac{1}{\left(1+K_{\mathrm{L}} C_{0}\right)},
$$

where $R_{\mathrm{L}}$ is a dimensionless separation factor indicating the shape of the isotherm, $K_{\mathrm{L}}$ is the Langmuir constant and $C_{0}$ is the initial $\mathrm{Ca}$ (II) concentration. The Langmuir isotherm is favorable when $R_{\mathrm{L}}<1$, which is in a good agreement with the calculated data, i.e. $R_{\mathrm{L}}=0.0008$ and 0.0005 for the $\mathrm{NaP}$ zeolite samples made with $\mathrm{Na}_{2} \mathrm{O} / \mathrm{SiO}_{2}$ of 1.10 and 1.13, respectively, which indicate the favorable adsorption of $\mathrm{Ca}(\mathrm{II})$ onto both samples.

Instead, the Freundlich isotherm model assumes the heterogeneous surfaces of adsorption isotherm. The Freundlich equation is commonly given as follows [37]:

$$
\ln q_{\mathrm{e}}=\ln K_{\mathrm{F}}+\frac{1}{n} \ln C_{\mathrm{e}},
$$

where $K_{\mathrm{F}}\left(\mathrm{L} \mathrm{g}^{-1}\right)$ is the Freundlich constant, whose value indicates the adsorption capacity of the adsorbent, and $1 / n$ is the Freundlich coefficient. By plotting $\ln \left(q_{\mathrm{e}}\right)$ vs. $\ln \left(C_{\mathrm{e}}\right)$, a straight line was obtained, where the values of $n$ and $K_{\mathrm{F}}$ can be determined from the slope and intercept, respectively (Table 2 ). The results indicate that the $1 / n$ value was less than unity for both zeolites, suggesting more facile adsorption of $\mathrm{Ca}$ (II) ions. Further, the $R^{2}$ for the $\mathrm{NaP}$ zeolite with the $\mathrm{Na}_{2} \mathrm{O} / \mathrm{SiO}_{2}$ molar ratio of 1.13 was higher than the corresponding of 1.10, thus the experimental data of the former presents a better fit to the Freundlich isotherm.

The adsorption values were compared with the literature data in Table 2. Our results are in the range of cited values in the literature, where for instance Qin et al. $[38,39]$ found that zeolite $\mathrm{P}$ had a maximum adsorption capacity for $\mathrm{Ca}^{2+}$ of $92.5 \mathrm{mg} \mathrm{g}^{-1}$. Meanwhile, Kabwadza et al. [40] reported a higher adsorption value, i.e. $250 \mathrm{mg} \mathrm{g}^{-1}$.

\section{Kinetic analysis}

The kinetics of adsorption of $\mathrm{Ca}$ (II) onto both $\mathrm{NaP}$ zeolite samples were inspected through the pseudo-first-order and pseudo-second-order kinetic models. The linearized-integral form of the pseudo-first-order model [41] is expressed as

$$
\log \left(q_{\mathrm{e}}-q_{t}\right)=\log q_{\mathrm{e}}-\frac{K_{1} t}{2.303}
$$

where $q_{\mathrm{e}}$ and $q_{t}$ are the amounts $\left(\mathrm{mg} \mathrm{g}^{-1}\right)$ of $\mathrm{Ca}(\mathrm{II})$ adsorbed onto $\mathrm{NaP}$ at equilibrium time and at any instant of time $t$, respectively. $K_{1}\left(\mathrm{~min}^{-1}\right)$ is the pseudo-first-order reaction rate constant which is evaluated by plotting $\log \left(q_{\mathrm{e}}-q_{t}\right)$ $v s$. $t$. The parameter values of the kinetic models at various $\mathrm{Ca}(\mathrm{II})$ concentrations are listed in Table 2 . Here, the $R^{2}$ values are relatively low for both samples which implys that the adsorption does not fit well to the pseudo-first-order model.

Instead, the pseudo-second-order model assumed that the rate of a chemical exchange reaction occurring on the adsorbent surface may describe the number of adsorption sites available for the exchange as expressed by [42]

\begin{tabular}{|c|c|c|c|c|c|c|c|c|c|c|c|c|c|}
\hline \multirow[b]{2}{*}{ Sample NaP } & \multicolumn{4}{|c|}{ Langmuir } & \multicolumn{3}{|c|}{ Freundlich } & \multicolumn{2}{|c|}{ Pseudo $1^{\text {st }}$ order } & \multicolumn{3}{|c|}{ Pseudo $2^{\text {nd }}$ order } & \multirow[t]{2}{*}{ Ref. } \\
\hline & $\begin{array}{c}q_{\mathrm{m}} \\
\left(\mathrm{mg} \mathrm{g}^{-1}\right)\end{array}$ & $\begin{array}{c}K_{\mathrm{L}} \\
\left(\mathrm{L} \mathrm{mg}^{-1}\right)\end{array}$ & $R_{\mathrm{L}}$ & $R^{2}$ & $\begin{array}{c}K_{\mathrm{F}} \\
\left(\mathrm{mg} \mathrm{g}^{-1}\right)\end{array}$ & $1 / n$ & $R^{2}$ & $\begin{array}{c}K_{1} \\
\left(\min ^{-1}\right)\end{array}$ & $R^{2}$ & $\begin{array}{c}k_{2} \\
\left(\mathrm{~g} \mathrm{mg}^{-1} \min ^{-1}\right)\end{array}$ & $\begin{array}{c}q_{\mathrm{e}} \\
\left(\mathrm{mg} \mathrm{g}^{-1}\right)\end{array}$ & $R^{2}$ & \\
\hline $\mathrm{Na}_{2} \mathrm{O} / \mathrm{SiO}_{2}=1.10$ & 170 & 82.3 & 0.0008 & 0.998 & 3.874 & 0.156 & 0.855 & 0.360 & 0.843 & 0.063 & 0.219 & 0.978 & \multirow{2}{*}{ Our work } \\
\hline $\mathrm{Na}_{2} \mathrm{O} / \mathrm{SiO}_{2}=1.13$ & 147 & 132.5 & 0.0005 & 0.983 & 3.820 & 0.143 & 0.945 & 0.884 & 0.902 & 0.076 & 0.059 & 0.993 & \\
\hline \multirow{2}{*}{ Literature work } & 250 & I & 0.0027 & 0.96 & 4.0 & 0.588 & 0.94 & l & I & I & I & l & {$[40]$} \\
\hline & 92.50 & 2.06 & 0.247 & 0.994 & 42.20 & 0.136 & 0.905 & 0.305 & 0.997 & 0.0073 & 0.975 & 0.999 & {$[38,39]$} \\
\hline
\end{tabular}

$$
\frac{t}{q_{t}}=\frac{1}{k_{2} q_{\mathrm{e}}^{2}}+\frac{t}{q_{\mathrm{e}}},
$$

Table 2 Kinetic parameters for $\mathrm{Ca}^{2+}$ adsorption on Ca-selective zeolite 
where $q_{\mathrm{e}}\left(\mathrm{mg} \mathrm{g}^{-1}\right)$ is the quantity of $\mathrm{Ca}(\mathrm{II})$ adsorbed at equilibrium state, $q_{t}$ adsorbent at time $t$, and $k_{2}$ $\left(\mathrm{g} \mathrm{mg}^{-1} \mathrm{~min}^{-1}\right)$ is the pseudo-second-order reaction rate constant. By plotting $t / q_{t}$ against $t$, we can obtain $k_{2}$ and $q_{\mathrm{e}}$ from the intercept and the slope, respectively. Here, the results obtained from the analysis of the $\mathrm{Ca}$ (II) adsorption on both samples correspond to $0.99 \leqslant R^{2}<1.00$. Hence, the obtained experimental kinetic data fit well with pseudo-second-order kinetic equation. The higher the $\mathrm{Na}_{2} \mathrm{O}$ / $\mathrm{SiO}_{2}$ molar ratio, the higher pseudo-second-order rate constant was observed. The reason comes from the effects of total basicity in the higher $\mathrm{Na}_{2} \mathrm{O} / \mathrm{SiO}_{2}$ sample which may drive the $\mathrm{Ca}(\mathrm{II})$ adsorption to the zeolite surface faster. The higher $\mathrm{Na}_{2} \mathrm{O} / \mathrm{SiO}_{2}$ ratio (1.13) has been proven to allow the crystalline aluminosilicate to be formed due to the role of stabilization, thus have more sites for the $\mathrm{NH}_{3}$ adsorption via $\mathrm{NH}_{3}$-TPD data. From the TPD results, the LT peak at $381^{\circ} \mathrm{C}$ for $\mathrm{NaP}$ with $\mathrm{Na}_{2} \mathrm{O} / \mathrm{SiO}_{2}$ (1.13) reveals the weakly molecular bonding state of $\mathrm{NH}_{3}$, and most likely corresponds to Freundlich adsorption. The HT peak at $442^{\circ} \mathrm{C}$ indicates the dissociation of the $\mathrm{NH}_{4}^{+} / \mathrm{ZeO}^{-}$ionpair complex, which plausibly thought to be due to $\mathrm{NH}_{3}$ molecules bind to the strong acid sites located on zeolite surface. In this case, one can use this peak to represent the Langmuir adsorption.

\section{CONCLUSIONS}

The NaP zeolite was successfully synthesized via a free template hydrothermal route with well-defined size and morphology control. The optimized combination of many factors such as inorganic components in the starting hydrogel can decisively control the synthesis of $\mathrm{NaP}$ zeolite especially the $\mathrm{NaO}_{2} / \mathrm{SiO}_{2}$ molar ratio. The physicochemical characterization showed that the optimized product in the synthesis of zeolite $\mathrm{NaP}$ was obtained at the $\mathrm{Na}_{2} \mathrm{O} / \mathrm{SiO}_{2}$ molar ratio of 1.10-1.13, and aging temperature and time of $100^{\circ} \mathrm{C}$ and 4 days, respectively. The $\mathrm{Na}$ (I) cation was found to play an important structure-directing role in enhancing the nucleation and thermal stability of $\mathrm{NaP}$ zeolite crystals. Therefore, no exothermic peaks related to phase transitions of the materials up to $1000^{\circ} \mathrm{C}$ were observed in the DSC curves. The $\mathrm{NH}_{3}$-TPD profile revealed two desorption ammonia peaks at 381 and $442^{\circ} \mathrm{C}$ for both samples. The latter with the $\mathrm{Na}_{2} \mathrm{O} / \mathrm{SiO}_{2}$ molar ratio of 1.13 has been found to possess a much higher population of acid sites on its external surface at $381^{\circ} \mathrm{C}$. The Langmuir isotherm model provided the best fit for a sample made with the $\mathrm{Na}_{2} \mathrm{O}$ / $\mathrm{SiO}_{2}$ ratio of 1.10 , whereas Freundlich isotherm model successfully applied to that of 1.13 . Kinetic parameters showed that the adsorption of $\mathrm{Ca}$ (II) onto zeolite $\mathrm{NaP}$ for both samples was described best by pseudo-second order model confirming that this sorbent was chemically controlled. This happened with a shorter time required for reaching the equilibrium.

Received 2 July 2015; accepted 6 August 2015;

published online 19 August 2015

1 Zubowa HL, Kosslick H, Mueller D, et al. Crystallization of phasepure zeolite NaP from MCM-22-type gel compositions under microwave radiation. Micropor Mesopor Mater, 2008, 109: 542-548

2 Meftah M, Oueslati W, Amara ABH. Synthesis process of zeolite P using a poorly crystallized kaolinite. Phys Procedia, 2009, 2: 1081-1086

3 Cao JL, Liu XW, Fu R, Tan ZY. Magnetic P zeolites: synthesis, characterization and the behavior in potassium extraction from seawater. Sep Purif Technol, 2008, 63: 92-100

4 Huang Y, Dong D, Yao J, et al. In situ crystallization of macroporous monoliths with hollow nap zeolite structure. Chem Mater, 2010, 22: 5271-5278

5 Wang F, Wu D, He S, et al. Property characterization of NaP1 zeolite from coal fly ash by hydrothermal synthesis. J Mater Eng, 2005, 8: 47

6 Dua YC, Shia SL, Daib HX. Water-bathing synthesis of high-surface-area zeolite P from diatomite. Particuology, 2011, 9: 174-178

7 Dong JH, Lin YS. In situ synthesis of p-type zeolite membranes on porous a-alumina supports. Ind Eng Chem Res, 1998, 37: 24042409

8 Breck D. Zeolite Molecular Sieves. New York: John Wiley \& Sons, 1974

9 Brown GT, Osinga TJ, Parkington MJ. Steel AT. Zeolite P, process for its preparation and its use in detergent compositions. EP Patent 0384070, 1995

10 Kakansson L, Falth L, Hansen S. Structure of a high-silica variety of zeolite NaP. Acta Cryst C, 1990, 46: 1363-1364

11 Atkins M, Glasser FP, Jack JJ. Zeolite P in cements: its potential for immobilizing toxic and radioactive waste species. Waste Manage, 1995, 15: 127-135

12 Nery JG, Mascarenhas YP, Cheetham AK. A study of the highly crystalline, low-silica, fully hydrated zeolite $\mathrm{P}$ ion exchanged with $\left(\mathrm{Mn}^{2+}, \mathrm{Cd}^{2+}, \mathrm{Pb}^{2+}, \mathrm{Sr}^{2+}, \mathrm{Ba}^{2+}\right)$ cations. Micropor Mesopor Mater, 2003, 57: 229-248

13 Sathupunya M, Gulari E, Wongkasemjit S. ANA and GIS zeolite synthesis directly from alumatrane and silatrane by sol-gel process and microwave technique. J Eur Ceram Soc, 2002, 22: 2305-2314

14 Murayama N, Yamamoto H, Shibata J. Mechanism of zeolite synthesis from coal fly ash by alkali hydrothermal reaction. Int J Miner Proc, 2002, 64: 1-17

15 Kazemian H, Naghdali Z, Kashani TG, Farhadi F. Conversion of high silicon fly ash to Na-P1 zeolite: alkaline fusion followed by hydrothermal crystallization. Adv Powder Technol, 2010, 21: 279-283

16 Mullins LJ, Tiffert T, Vassort G, Whittembury J. The effects of internal $\mathrm{Na}^{+}$and $\mathrm{H}^{+}$and of external $\mathrm{Ca}^{+2}$ and membrane potential on $\mathrm{Ca}$ entry in squid axons. J Physiol, 1983, 338: 295-319

17 Vassort G, Whittembury J, Mulins LJ. Increases in internal $\mathrm{Ca}^{2+}$ and decreases internal $\mathrm{H}^{+}$are induced by general anesthetics in squid axons. J Biophys Soc, 1986, 50: 11-19

18 Kim SD, Noh SH, Park JW, Kim WJ. Organic-free synthesis of ZSM5 with narrow crystal size distribution using two-step temperature process. Micropor Mesopor Mater, 2006, 92: 181-188

19 Kim SD, Noh S H, Seong KH, Jung Kim W. Compositional and ki- 
netic study on the rapid crystallization of ZSM-5 in the absence of organic template under stirring. Micropor Mesopor Mater, 2004, 72: $185-192$

20 Ali IO, Hassan AM, Shaaban SM, Soliman KS. Synthesis and characterization of ZSM-5 zeolite from rice husk ash and their adsorption of $\mathrm{Pb}^{2+}$ onto unmodified and surfactant-modified zeolite. Sep Purif Technol, 2011, 83: 38-44

21 Szostak R. Molecular Sieves: Principles of Synthesis and Identification, Van Nostrand Reinhold catalysis series. Amsterdam: Springer Netherlands, 1998, 123: 5

22 Barrer RM, White EAD. The hydrothermal chemistry of silicates. Part II. Synthetic crystalline sodium aluminosilicates. J chem Soc. 1952, 1561-1571

23 Zhdanov SP. Some problems of zeolite crystallization. Adv Chem Ser, 1971, 101: 20-43

24 Albert BR, Cheetham AK, Stuart JA, Adams CJ. Investigations on P zeolites: synthesis, characterisation, and structure of highly crystalline low-silica NaP. Micropor Mesopor Mater, 1998, 21: 133-142

25 Zhiping H, Xiangyu X, Zhi L, et al. Synthesis of zeolite NaP with controllable morphologies. Micropor Mesopor Mater, 2012, 158: $137-140$

26 Musyoka NM. Hydrothermal Synthesis and Optimisation of Zeolite Na-P1 from South African Coal Fly Ash. MSc thesis, Cape Town: University of the Western Cape, 2009

27 Ali IO, Thabet MS, El-Nasser KS, Hassan AM, Salama TM. Synthesis of nanosized ZSM-5 zeolite from rice straw using lignin as a template: surface-modified zeolite with quaternary ammonium cation for removal of chromium from aqueous solution. Micropor Mesopor Mater, 2012, 160: 97-105

28 Pal P, Das JK, Das N, Bandyopadhyay S. Synthesis of NaP zeolite at room temperature and short crystallization time by sonochemical method. Ultrasonics Sonochemis, 2013, 20: 314-321

29 Mohamed MM, Salama TM, Othman I, Abd Ellah I. Synthesis of high silica mordenite nanocrystals using o-phenylenediamine, $\mathrm{Mi}$ cropor Mesopor Mater. 2005, 84: 84-96

30 Katada N, Niwa M. Analysis of acidic properties of zeolitic and non-zeolitic solid acid catalysts using temperature-programmed desorption of ammonia. Catal Surv Asia, 2004, 8: 161-170

31 Rodríguez-González L, Rodríguez-Castellón E, Jiménez-López A,
Simon U. Correlation of TPD and impedance measurements on the desorption of $\mathrm{NH}_{3}$ from zeolite H-ZSM-5. Solid State Ion, 2008, 179: 1968-1973

32 Li X, Li B, Xu J. Synthesis and characterization of transitional metal-rich zeolite $\mathrm{M}$-MFI $(\mathrm{M}=\mathrm{Fe}, \mathrm{Co}, \mathrm{Ni}, \mathrm{Cu})$ with regular mesoporous channels. Colloid Surf A Physicochem Eng, 2013, 434: 287-295

33 Rouquerol F, Rouquerol J, Sing KSW, et al. (eds.). Handbook of Porous Materials, Vol. 1. Weinhiem: Wiley-VCH, 2002, 250

34 Zhiping H, Xiangyu X, Lü Z, et al. Synthesis of zeolite NaP with controllable morphologies. Micropor Mesopor Mater, 2012, 158: 137-140

35 Horvath G, Kawazoe K. Method for the calculation of effective pore size distribution in molecular sieve carbon. J Chem Eng Jpn, 1983, 16: $470-475$

36 Webber TW, Chakkravorti RK. Pore and solid diffusion models for fixed-bed dsorbers. AIChE J, 1974, 20: 228-238

37 Freundlish HMF. Over the adsorption in solution. J Phys Chem, 1906, 57: 385-470

38 Qin C, Wang R, Ma W. Adsorption kinetic studies of calcium ions onto Ca-selective zeolite. Desalination, 2010, 259: 156-160

39 Qin C, Wang R, Ma W. Characteristics of calcium adsorption by Ca-selectivity zeolite in fixed-pH and in a range of $\mathrm{pH}$. Chem Eng J, 2010, 156: 540-545

40 Kabwadza-Corner P, Munthali MW, Johan E, Matsue N. Comparative study of copper adsorptivity and selectivity toward zeolites. Amer J Anal Chem, 2014, 5: 395-405

41 Lagergren S. About the theory of so-called adsorption of soluble substances. K Svenska Vetenskapsakad Handlingar Band, 1898, 24 : $1-39$

42 Singh KK, Rastogi R, Hasan SH. Removal of Cr(VI) from wastewater using rice bran. J Colloid Interface Sci, 2005, 290: 61-68

Author contributions Ali IO, Fodail H and El-Sheikh S designed, performed the experiments and the samples characterization. Ali IO, Salama TM and Bakr MF wrote the paper, made the general discussion and replied to comments posted by reviewers.

Conflict of interest The authors declare that they have no conflict of interest. 


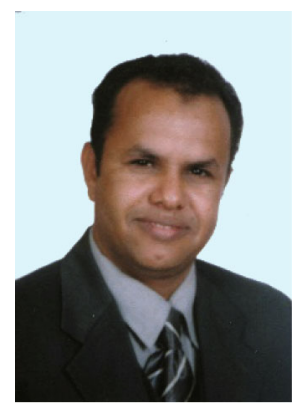

Ibraheem O. Ali received his BSc and PhD degrees from Chemistry Department, Faculty of Science, Al-Azhar University in the field of inorganic chemistry. Recently, he has been promoted as a professor of material science and catalysis at the Faculty of Science, Al-Azhar University. His research interests include zeolite synthesis, materials design and surface modification.

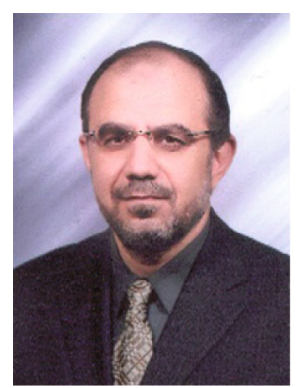

Tarek M. Salama was born in Cairo, Egypt. He received his BSc and PhD degrees from Al-Azhar University (Cairo, Egypt) and Hokkaido University (Sapporo, Japan), respectively. He then obtained a postdoctoral position in prof. Hediki Hattori's earth and environmental science lab in 1991. He joined the Catalysis Research Center (CRC), Hokkaido University, Japan (1993-1997) as a research professor where he worked with prof. Masaru Ichikawa on gold/NaY and gold/ZSM-5 systems for chemical, environmental and other industrial applications. As a professor of material science at the Faculty of Science, Al-Azhar University, his research interests focus on controlled synthesis of zeolites, assembly of inorganic nanomaterials and tailored design of carbon-based materials like nano ferrites loaded into nano graphene oxide and graphene.

中文摘要 本文通过无模板水热法在 $100^{\circ} \mathrm{C}$ 条件下制备了 $\mathrm{NaP}$ 沸石分子笁, 并研究了 $\mathrm{Na}_{2} \mathrm{O} / \mathrm{SiO}_{2}$ 和 $\mathrm{SiO}_{2} / \mathrm{Al}_{2} \mathrm{O}_{3}$ 摩尔比、凝胶老化时间和 老化温度等参数, 以调节最终产品的结晶度. 不同合成阶段的样品, 用 $-196^{\circ} \mathrm{C}$ 氮吸附、场发射扫描电子显微镜 $(\mathrm{FE}-\mathrm{SEM})$ 、氨程序升温 脱附、X-射线衍射、热重和差示扫描量热分析以及傅里叶变换红外光谱法进行了表征. 实验结果表明, 在 $\mathrm{Na}_{2} \mathrm{O} / \mathrm{SiO}_{2}$ 和 $\mathrm{SiO}_{2} / \mathrm{Al}_{2} \mathrm{O}_{3}$ 摩尔 比分别为 1.10 和 $1.40,100^{\circ} \mathrm{C}$ 温度下老化 4 天, 可以获得高度有序结晶化的 $\mathrm{NaP}$ 分子篮. $\mathrm{FE}-\mathrm{SEM}$ 图像显示 $\mathrm{NaP}$ 分子篮的多晶聚集体晶粒尺 寸可达 $5.04 \mu \mathrm{m}$, 具有仙人掌/卷心菜样结构. 定量分析发现酸位点总数随 $\mathrm{Na}_{2} \mathrm{O}$ 的增加而增加, $\mathrm{Na}_{2} \mathrm{O} / \mathrm{SiO}_{2}$ 摩尔比为 1.13 的 $\mathrm{NaP}$ 沸石样品 与 1.10 摩尔比合成的样品相比, 在外表面上具有大量的酸位点. 优化后的 $\mathrm{NaP}$ 分子篮在水溶液中具有优异的钙离子吸附性能, 本文对 钻离子吸附动力学参数进行了详细研究. 